Political economy embraces the complex

political nature of decision making to investigate how power and authority affect economic choices in

a society. Political economy analysis offers no quick fixes but leads to smarter engagement.

\title{
Political Economy Analysis for Development Effectiveness
}

\section{By Olivier Serrat}

\section{Define:Political Economy}

Economics - the social science that deals with the production, distribution, and consumption of material wealth and with the theory and management of economic systems or economies ${ }^{1}$ was once called political economy. ${ }^{2}$ Anchored in moral philosophy, thence the art and science of government, this articulated the belief in the 18 th-19th centuries that political considerations - and the interest groups that drive themhave primacy in determining influence and thus economic outcomes at (almost) any level of investigation. However, with the division of economics and political science into

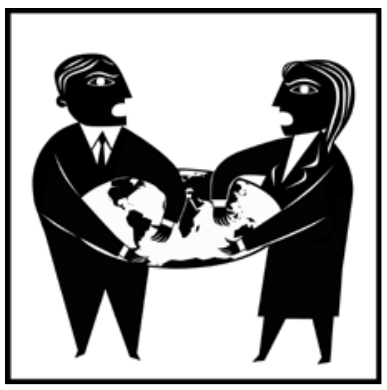
distinct disciplines from the 1890 s, neoclassical economists turned from analyses of power and authority to models that, inherently, remove much complexity from the issues they look into. ${ }^{3}$

Today, political economists study interrelationships between political and economic institutions (or forces) and processes, which do not necessarily lead to optimal use of scarce resources. ${ }^{4}$ Refusing to eschew complexity, they appreciate politics as the sum

There is no universally accepted definition of economics. Two other characterizations that both place an accent on scarcity consider it the study of (i) the forces of supply and demand in the allocation of scarce resources, and (ii) individual and social behavior for the attainment and use of the material requisites of economic well-being as a relationship between given ends and scarce means that have alternative uses. The field is subdivided into microeconomics - which characteristically examines the behavior of individual consumers, groups of consumers, or firms - and macroeconomics - which ordinarily looks at growth, inflation, unemployment, and the role of government.

Antoine de Montchrestien (1575-1621), a French poet, dramatist, and economist, is credited with the first use of the term.

3 Power refers to the ability of an individual or group to achieve outcomes reflecting objectives. (Some distinguish hard and soft power.) Authority exists whenever an individual or group is permitted to control, command, or determine. (Some distinguish formal and informal authority.) At heart, politics is but the struggle for the acquisition and application of power and authority.

4 If economics is the study of the optimal use of scarce resources, subject to well-defined constraints and a market environment, political economy embraces the complex political nature of decision making to investigate how power and authority affect economic choices in a society. 
of activities - involving cooperation, conflict, and negotiation - that shape decisions touching the production, consumption, and transfer of scarce resources, irrespective of whether the activities are formal or informal, public or private, or a combination thereof. ${ }^{5}$ (Lest this compass be thought beyond reach, it should be pointed out that politics are not normally random and therefore unpredictable.) In summary, they analyze and explain the ways in which governments affect the allocation of scarce resources in society through laws and policies and, by the same token, the ways in which the nature of economic systems and the behavior of people acting on their economic interests impact governments and the laws and policies they formulate. Depending on the outlook, they can thereby, for example, bring a focus to bear on outcomes - practices might be a better termsuch as inequality or exclusion.

It is only the novice in political economy who thinks it is the duty of government to make its citizens happy.-Government has no such office. To protect the weak and the minority from the impositions of the strong and the majority - to prevent anyone from positively working to render the people unhappy, (if we may so express $i t$,) to do the labor not of an officious inter-meddler in the affairs of men, but of a prudent watchman who prevents outragethese are rather the proper duties of a government.

-Walt Whitman

\section{A Précis on Political Economy Analysis}

Obviously, questions of power and authority come to the fore when heterogeneity of interest leads to conflict ${ }^{6}$ among actors in a society. ${ }^{7}$ Political economy is founded on the predicament of economic choices in a society comprising heterogeneous agents. Its focus is different from that of welfare economics: ${ }^{8}$ the issue is not the technical problem of what implications different welfare weights might have but the political problem of how weights are ascribed and the processes associated with that. (Simplifying, technical and informational approaches ask "what" questions; political economists ask "why" first, and then "how," taking political feasibility into account. This shifts attention from what is missing to what there is.)

In a nutshell, political economy analysis investigates the interaction of political and economic processes in a society; this entails comprehending

- the power and authority of groups in society, counting the interests they hold and the incentives that drive them, in conducing particular outcomes;

- the role that formal and informal institutions play in allocating scarce resources;

- the influence that values and ideas, including culture, ideologies, and religion, have on shaping human relations and interaction.

5 The approach is impartial in that it neither presupposes nor favors a particular type of polity or mode of decision making, policy package or development strategy, structure of incentives, or scale of application. However, by explaining outcomes, it helps diagnose possible sources of positive change - or, conversely, opposition — as well as their dynamics.

6 Conflict may be defined as a disagreement, contest, or struggle between people with opposing beliefs, concerns, goals, ideas, interests, needs, or values. Conflict often connotes with war or violence but it occurs more commonly at all levels of society in all sorts of situations. (Some think it is an unavoidable aspect of everyday life.) Surface conflict has shallow or no roots; it often owes to misunderstanding and can be addressed by improved communications and the conscious effort of opposing groups to understand one another. Latent conflict is conflict below the surface; it might have to be brought out into the open before it can be effectively addressed. Open conflict is very visible and has deep roots, sometimes spanning generations. Because it causes more physical, social, psychological, and environmental damage than the other types, both its causes and effects need to be addressed.

7 This is where economics falls short: the optimal solutions it seeks, subject to technical and informational constraints, will not eventuate where conflict exists yet collective choices must nevertheless still be made.

8 Welfare economics uses microeconomic techniques to evaluate, under conditions of competitive equilibrium and with due concern for economic efficiency and the income distribution associated with that, what economic policies will create the highest overall level of social good. 


\section{Political Economy Analysis for Development Effectiveness}

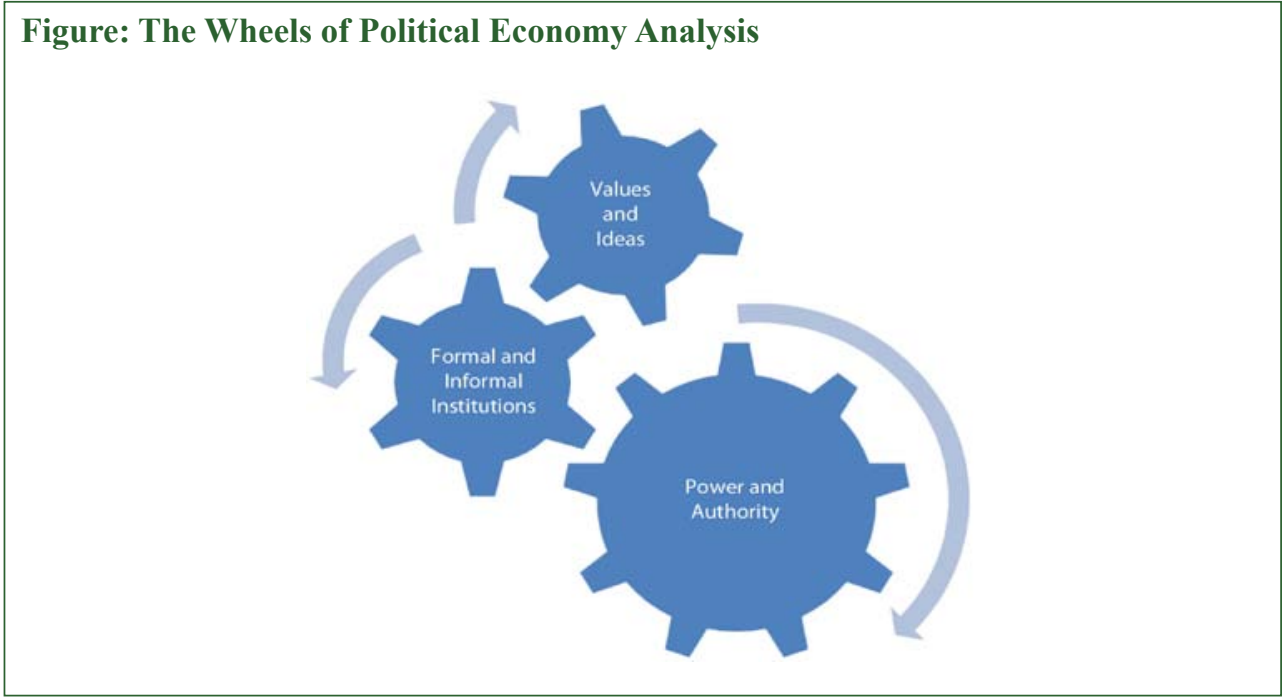

Source: Author.

Naturally, bilateral and multilateral development agencies seek to maximize the quality and impact of the assistance they extend. ${ }^{9}$ For this, since development is not a technocratic process but fundamentally political, they must gain a "real-world" sense of what is possible; only then can they with knowledge expand the feasible space for reform, engage, and help actors surmount what might otherwise be impossible. ${ }^{10}$ To this intent, problem-driven, dynamic, and actionable political economy analysis can, for instance, (i) contribute to deeper understanding of political context and how it affects pro-poor development assistance; (ii) lead to more politically astute - and therefore more realistic and effective - country partnership strategies and related programming, including the selection of lending and nonlending modalities, through the identification of pragmatic solutions to challenges; (iii) support scenario planning and risk management by helping identify critical factors apt to drive or obstruct positive change; (iv) broaden the scope for quality dialogue among and engagement by clients, audiences, and partners around key political challenges and opportunities, for example, at country, sector or thematic, and policy or project levels; ${ }^{11}$ (v) foster coherence across joint goals through a common analysis of the underlying political and economic processes shaping development; and (vi) build coalitions for innovative or "good enough" change. The boxes below illustrate how a political economy perspective might add value to development work by changing the way it is conducted.

9 Quite simply, even if it is never easy to achieve it in practice, development effectiveness refers to the extent to which development interventions accomplish their objectives. The Paris Declaration on Aid Effectiveness of 2005 outlined five fundamental principles for making aid more effective: (i) ownership-developing countries set their own strategies for poverty reduction, improve their institutions, and tackle corruption; (ii) alignment-donor countries align behind these objectives and use local systems; (iii) harmonization-donor countries coordinate, simplify procedures, and share information to avoid duplication; (iv) managing for results - developing countries and donors shift focus to development results and results get measured; and (v) mutual accountability- developing countries and donors are accountable for development results.

10 The mandates of bilateral and multilateral development agencies usually —and explicitly — preclude them from engaging in politics. Notwithstanding, it is common sense that they must understand political economy contexts from a diagnostic-not prescriptiveperspective if they are to successfully help design and implement development policies and strategies.

11 Of course, the different levels can be and often are combined. Broadly, country-level analysis would delve on interactions among structural variables, institutional variables, and agents (aka actors or stakeholders). Sector- or thematic-level analysis would scrutinize roles and responsibilities, ownership structure and financing, power relations, historical legacies, corruption and rent-seeking, service delivery, decision making, implementation issues, and potential for reform. Policy- or project-level analysis would identify the problem, issue, or vulnerability to be addressed; map out the institutional and governance weaknesses that cause it; and drill down to the specific issues that constrain or might support progressive change. See also Department for International Development. 2009. Political Economy Analysis: How-To Note. Available: www.odi.org.uk/events/documents/1929-dfid-note-political-economy-analysis.pdf. In guidance to its offices, the department notes that several elements of the framework for political economy analysis cut across the three levels: they are (i) legitimacy; (ii) inputs in the form of influences, demands, and oppositions; (iii) inputs in the form of supports and withdrawals; (iv) modes of inputs, e.g., advice, conditionality, terms, threat, or treaties where inputs are external and discourse, ideas, petitions, or votes where they are internal; (v) gatekeepers; (vi) decision-making power maps; (vii) lobbying; (viii) decision making; (ix) outputs; (x) capacity and the politics of implementation; and (xi) feedback effects. 


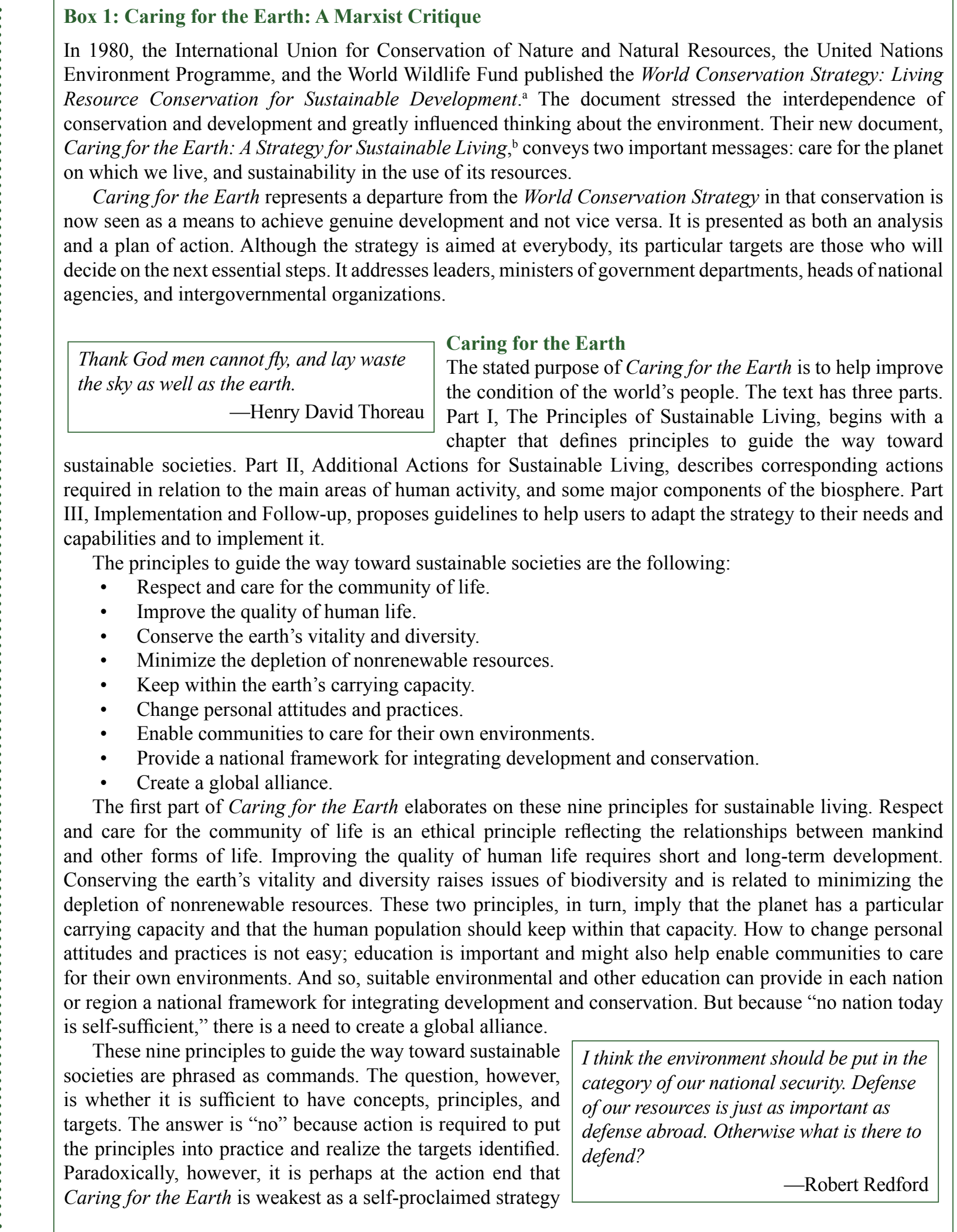


for sustainable living. Only one chapter is given over to this, listing 132 actions that would be required to pull off the strategy for sustainable development. It is, nonetheless, up to governments, nongovernment organizations, and people to consider which of these actions they can and should take. Judging Caring for the Earth by the standards called for by its avowed intentions, therefore, the reader may wonder what use to make of such directives as to

- Develop the world ethic for living sustainably.

- Prepare for climate change.

- Develop more effective local governments.

- Build up the global alliance.

Marx to the Rescue

Still, the faults of Caring for the Earth are more serious than its failure to present anything more than a potpourri of directives. Put bluntly, many conservationists now promoting conservation programs threaten merely to pay lip service to the social contexts within which they propose to operate their systems of management. Despite the superficially attractive approach of such initiatives as Caring for the Earth in seeking to enlist the integration of development goals with conservation objectives and the participation of local people, some of the assumptions that underlie these initiatives are disturbing. At heart, Caring for the Earth intimates that the conservationists' utopian vision of society must predominate. Although the document appraises aspects of socioeconomic and political organization which have brought about environmental degradation and social deprivation, the strategy it advocates does not even begin to examine the social and political changes that

We never know the worth of water till the well is dry.

- Thomas Fuller would be necessary to meet the conservation goals set out in Part II of the document. As seen by Marxists, Caring for the Earth reflects the narrow academic or ideological preoccupations of the specialists who formulated it.

Environmental problems are rarely environmental in origin. A study of environmental destruction in southern Honduras by Susan Stonich concludes that environmental degradation arises from social structure and is intricately connected to land tenure, unemployment, poverty, and demography. She identifies political and economic factors and export-promotion policies of international lending institutions and aid agencies as the key element of a development policy for the whole of Central America that is likely to lead to destruction of the remaining tropical forests, worsen poverty and malnutrition, and increase inequality and conflicts within and between nations. To those that subscribe to the political economy perspective, therefore, the biological explanation offered by conservationists and ecologists is simplistic and overlooks the social context of development and land distribution within which worldwide destruction of traditional agriculture and the rain forests is now occurring.

From a perspective that combines the concerns of political economy, then, the environmental management proposed in Caring for the Earth is ahistorical in the sense that it ignores the importance of modes of production. It presents environmental dilemmas in terms of fixed and unchanging limits upon human action. This means that the document deals primarily with symptoms, not causes, and that it places the environment above people despite recurring statements to the contrary. Such biological explanations are deterministic, conceal the choices that are open to people to change their society and their own destiny, and can lead to pessimism about man's ability to create harmony with nature through social reform.

At root, documents such as Caring for the Earth offer no structural changes to redress "underdevelopment," to use a once popular coinage, and their appeals on behalf of the planet are little more than calls for the survival of the industrial system. Changes are advocated without any analysis of how mismanagement came about that would in all likelihood lead to increased polarization in the economy and the society penalizing people for actions resulting from their own poverty. An alternative, political economy, perception would not have social, economic, or technical factors explain environmental dilemmas but rather depict the environmental situation examined as evidence of a social, economic, or political dilemma, laying emphasis on such factors as inequality in resources and power and structural "underdevelopment." David Pepper ${ }^{\mathrm{d}}$ contends that, 
as seen by Marxists, "This is politically reactionary, leading to repressive attitudes which are legitimated through the appeal to an 'objective' science and a pretence that environmental problems are 'above politics'." The environmental movement maintains a facade of technical objectivity which, a Marxist critique would argue, provides new techniques for members of the elite to gain professional status, notably through articles in specialized journals.

And, indeed, "Caring for the Earth is intended to be used by those who shape policy and make decisions that affect the course of development and the condition of our environment." Almost as an afterthought, it is also considered to be of use to other citizens in communities and settlements everywhere. The approach, which corresponds to the appeal for an "objective" science, is dogmatic. Readers are directed to engage in certain activities and refrain from others.

Societies, however, are neither mere population aggregates nor unified biotic communities. Rather, they are specified by their mode of production. Crisis tendencies and profit generation constitute the core of societal development, which is dominated by the capital accumulation process. Questions to be asked and answered are: What is the character of power and inequality? How do they relate to ecological patterns? How do production and reproduction processes of capital accumulation, as well as the processes of crisis adjustment, manifest themselves in sociospatial organization? Caring for the Earth does not raise such questions, let alone attempt to answer them, and its attempt to enthrone conservation

We do not inherit the earth from our ancestors; we borrow it from our children.

-Anonymous

as a means to sustainable development is, at best, awkward. Conservation, which can be defined as the management, protection, and preservation of the earth's natural resources and environment, has opportunity costs. These are the development benefits foregone. Yet, Caring for the Earth argues that its aim is sustainable development.

\section{What Next?}

The dilemmas facing mankind are extreme but not new. Those living in affluence have often taken it for granted that the poor should pay the price of their wealth and comfort. From a Marxist perspective, one would say that class struggle, against which history is played out, continues unabated. And that in the struggle for survival some countries and some social classes will manage better than others. But sustainable development, if it is to find expression in reality, would require changes in modes of production and consumption as well as new social and political structures.

To make development sustainable, progress must be made to integrate the perspectives of three

And Man created the plastic bag and the tin and aluminum can and the cellophane wrapper and the paper plate, and this was good because Man could then take his automobile and buy all his food in one place and He could save that which was good to eat in the refrigerator and throw away that which had no further use. And soon the earth was covered with plastic bags and aluminum cans and paper plates and disposable bottles and there was nowhere to sit down or walk, and Man shook his head and cried: "Look at this Godawful mess."

-Art Buchwald disciplines: (i) that of economists, whose methods seek to maximize human welfare within the constraints of existing capital stock and technologies; (ii) that of ecologists, who stress the preservation of ecological subsystems; and (iii) that of sociologists, who emphasize that the key actors are human beings, whose patterns of social organization are crucial for devising viable solutions.

Sadly, sociological approaches, even when application oriented, have been largely timid, inactive, or simply reactive. In the case of environmental sociology, an explanatory factor is the difficulty of adapting bioecological concepts to the human context, which can pose problems of inappropriate or illegitimate use. And, at a more fundamental level, harsher critics of the political economy approach to the environment remark that natural resources were never at the center stage of Marxist thinking and that the environment was in any case rarely looked upon as a distributive issue. Nevertheless, 


\section{Political Economy Analysis for Development Effectiveness}

sociologists such as Edgar Borgatta ${ }^{\mathrm{e}}$ have sought to develop an important field called "proactive sociology"
to close the gap between sociological theory and practice. Rather than wait to study the aftereffects of
environmentally destructive activities or policies, when the problem is historically interesting but socially
irrelevant, proactive sociology would concern itself with the dynamics out of which dilemmas arise,
anticipating potential problem areas and their alternative solutions as the means to translate desired values
into effective policy. This would involve identifying possible futures and the consequences of action or
inaction for their attainment, a policy dimension that sociologists largely ignore.
Notwithstanding this critique of Caring for the Earth, therefore, it remains to be said that the document
and its forerunner, the World Conservation Strategy, are successful documents in environmental education.
Caring for the Earth significantly advances the framework established by the World Conservation Strategy.
To be fair, the reason for setting out the utopian model toward which we should progress is stated clearly:
"The world is running out of space and time."
a IUCN-UNEP-WWF. 1980. World Conservation Strategy: Living Resource Conservation for Sustainable Development. Gland, Switzerland.
b IUCN-UNEP-WWF. 1991. Caring for the Earth: A Strategy for Sustainable Living. Gland, Switzerland.
c Susan Stonich. 1989. The Dynamics of Social Processes and Environmental Destruction: A Central American Case Study. Population and
d Development Review. 15 (5). pp. 269-296.
e Eavid Pepper. 1984. The Roots of Modern Environmentalism. Croom Helm.
Sociology, Rome, Italy.

Source: Author. 1994. Unpublished.

\section{Box 2: Deforestation Benefits}

Forests provide countless products of vital use and are a source of livelihood to millions. For those reasons, abuse of forest resources has intensified dramatically in the wake of improved methods of exploitation, processing and transport, growth of external markets, and rapidly expanding populations. Since forests also play a key role in the ecosystem, deforestation has led to desertification, soil erosion, flooding, loss of biodiversity, and poorer environments for the poor. If that were not enough, some contend too that deforestation changes the atmospheric oxygen and carbon dioxide balance-which alters the albedo and accelerates the greenhouse effect. So, with growing unease about the consequences of deforestation, attention is shifting from production to conservation. Sadly, an environmental management perspective that ignores the environmental conflicts at hand sways it.

The Beneficiaries of Deforestation

Deforestation happens because it is profitable. That is why the perspective of those who gain from it, in conflict with one another, is of interest. The beneficiaries are

- Governments, since pioneer settlements divert attention from pressing social problems;

- National treasuries, which derive foreign exchange earnings from forest products;

- Commercial loggers (legal and illegal);

- People employed in the logging and wood-processing industries;

- Commercial interests that use deforested lands to grow a product for the market, speculate on land near roads and new settlements, and buy and sell charcoal or fuelwood;

- Local commercial businesses that benefit from frontier settlements;

- Urban consumers of charcoal and fuelwood, who pay a price that does not internalize the costs of deforestation;

- Consumers in industrialized countries, who also profit because the prices of tropical forest products do not reflect their true value;

- International corporations trading tropical forest products;

- Migrant farmers and shifting cultivators, who benefit from the removal of forest cover because it allows them to farm. ${ }^{\mathrm{a}}$ 


$$
\begin{aligned}
& \text { A virgin forest is where the hand of man } \\
& \text { has never set foot. }
\end{aligned}
$$

-Anonymous$$
\text { 西 }
$$
that use or influence forests have never received much notice. Yet, to control the process of deforestation, it is necessary to identify all those who benefit from it. Only then will policy, market, and institutional instruments for sustainable development work. ${ }^{\mathrm{b}}$

\section{A Framework for Conflict Resolution}

Demand for wood will rise by one third over the next 10 years. Worsening conflicts among forest users might be avoided if a cross-sectoral approach were adopted. Such an approach would identify all the sectors and groups that benefit from forests; define the benefits and establish objectives for sustaining and balancing them; and state how the objectives will be achieved. The intention would be to resolve conflicts by integrating compatible uses of forest resources or zoning where uses are incompatible. Solutions would permit the establishment of a stable forest continuum accommodating changing circumstances. Backed by (now) informed policy, Man has been endowed with reason, with the power to create, so that he can add to what he's been given. But up to now he hasn't been a creator, only a destroyer. Forests keep disappearing, rivers dry up, wildlife's become extinct, the climate's ruined and the land grows poorer and uglier every day.

-Anton Chekhov market, and institutional instruments, the continuum would encompass protected forests in their natural state, managed natural forests, shifting cultivation, agroforestry, and plantations.

\section{Toward Sustainable Forest Strategies}

Deforestation will be addressed most suitably by a multidisciplinary approach that emphasizes the socioeconomic and political environment in which deforestation takes place, against a pragmatic realization that societies (and forests) are dynamic. The advantages of social ingenuity over technical ingenuity should not be overlooked. A stable system of markets, legal regimes (including property rights), financial agencies, and institutions is a prerequisite to any economic and social progress. But developing countries are ill endowed with this social capital. And their ability to create and maintain it is being eroded by the very environmental problems they are hoping to address.

The benefits they derive are short-lived. The clearance process must be repeated elsewhere after a couple of years because of insect plagues, weeds, and soil impoverishment.

b Also, these instruments need to consider the motives of the agents of deforestation. The poor eke out a living and perform much of the expansion of agriculture into previously forested areas. But logging, some agriculture, and some charcoal making are carried out for commercial reasons.

Source: Serrat, O. 2001. Deforestation Benefits. Manila: ADB. Available: www.adb.org/documents/periodicals/ero/2001/deforestation.asp 


\section{Political Economy Analysis for Development Effectiveness}

\section{Box 3: A Note on Floods in Bangladesh}

Flood losses in Bangladesh grow despite large investments in flood control infrastructure. There are only two plausible explanations. They are a physically driven increase in the occurrence and importance of floods and a man-driven increase in vulnerability caused by denser floodplain occupancy. Deforestation is occurring in the Himalayan region. But, without evidence to support arguments that environmental degradation there is exacerbating floods in Bangladesh, it is generally accepted that human actions are on the whole responsible.

What is the appropriate behavior for a man or a woman in the midst of this world, where each person is clinging to his piece of debris? What's the proper salutation between people as they pass each other in this flood?

—Buddha
Even though floodplains are one of the more obvious hazard-prone environments, widespread invasion has occurred because of countless individual decisions based on the belief that locational benefits outweigh risks. Population pressures and general poverty have encouraged this expectation further. Once floodplains become urbanized, however, there follows an almost inevitable demand for flood protection from (now organized and vocal) local communities. This is because the construction of flood embankments or other physical controls is perceived to render part of the floodplains safe. Next, land values rise and the development of floodplains gathers steam (even though structural works cannot withstand the most powerful river flows and channel changes that threaten human life in disaster years). Development encourages further human encroachments and it becomes more and more difficult to shake off the massive structural legacy. Yet, in the meantime, flood embankments and other physical controls isolate fish farmers and jute farmers from the beneficial spread of monsoon floods in normal years.

International assistance may have advanced this trend. The Flood Action Plan prompted by heavy floods in 1987 and 1988 recommended greater reliance on embankments along the major rivers. This worked well at first. But some doubt the sustainability of the embankment program. It is long-term by nature and must be sustained to make sense, with the embankments raised every year to cope with the rising channel beds that result from deposition. And then again, history shows that the integrity of embankments is the exception rather than the rule.

Bangladesh may be in a no-win situation and failure to understand environmental management issues could have dire consequences. Experience confirms the need to develop more open systems of management permitting flexible attitudes to turbulent environments, where local community needs define the modi vivendi. Flood proofing - which entails going back to using floods as much as possible instead of trying to prevent or control them - may be a more appropriate behavioral approach preferable to structural responses. The latter usually aggravate the situation in many economic, social, ecological, and institutional ways and tend to impact the poorest most severely because they are not empowered to participate in making the decisions that shape their lives.

In Bangladesh, cost-benefit analysis of planned abandonment of the floodplain structures might show acceptable financial and economic returns that equal or surpass those from further investments in flood control infrastructure. Social analysis would reveal a complex of necessary concessions between winners and losers but the opportunities to avoid poverty and conflict would then be richer overall. Ecological analysis would undoubtedly indicate greater possibilities for a return to ecosystem health and vitality. Institutional analysis would show also the need for a more open society where public servants serve the people better and calm their engineering fervor to supply management services that encourage and sustain development outside the floodplains.

Source: Serrat, O. 2001. A Note on Floods in Bangladesh. Manila: ADB. Available: www.adb.org/documents/periodicals/ero/2001/floods-ban. asp 
s, or livestock can be managed to sustain yields. Techniques or short-term gain. But single explanations are always inadequate. economic circumstances that put pressure on the land users to manage rstanding why land users degrade land means embracing the range of A Chain of Explanations ..

eated land use decisions under specific conditions. Subtle (and not so Yet, they enter the picture somewhere along a chain of explanations. tion leading to land degradation become noticeable at a site- for by specific land use practices at the site (e.g., tree felling, plowing down slope, or planting crops that provide no ground cover Why does the land user treat the land in this way? Causes are found vel of explanation and knowledge that has to do with access to resources, skills, assets, and time horizons - to name a few-but also to the nature of agricultural society (including the distribution of rights to land, laws of inheritance, and the gender division of labor). Higher still, one can examine how the state affects land management through laws on tenure, prices, or agricultural extension. Finally, one can study important international forces that act through the state to affect land management. They relate to foreign debt, oil prices, or structural adjustment programs. To sum up, the chain of explanations pulls together:

- recognized physical changes at a site;

- symptoms affecting the land user;

- $\quad$ specific land use practices at the site;

- the resources, skills, assets, time horizon, and technologies of the land user;

- the makeup of agricultural society;

- the makeup of the state;

- the global economy.

... and Logical Interventions

In view of that, understanding why land degradation takes place necessitates a political economy perspective locating analyses within specific social formations and explaining development processes in terms of the costs and benefits that they carry for different social classes. Interventions can then be made at all points along the chain. They would seek to address the policy, market, and institutional failures that break or pervert the necessary correlations between scarcity and prices, costs and benefits, rights and responsibilities, and actions and consequences.

Source: Serrat, O. 2001. A Note on Land Degradation. Manila: ADB. Available: www.adb.org/documents/periodicals/ero/2001/land degradation.asp 


\section{Political Economy Analysis for Development Effectiveness}

\section{Further Reading}

ADB. 2008. Culture Theory. Manila. Available: www.adb.org/documents/information/knowledge-solutions/ culture-theory.pdf

2009a. Building Institutional Capacity for Development. Manila. Available: www.adb.org/documents/ information/knowledge-solutions/building-institutional-capacity-for-development.pdf

—. 2009b. Understanding Complexity. Manila. Available: www.adb.org/documents/information/ knowledge-solutions/understanding-complexity.pdf

. 2010. Enriching Policy with Research. Manila. Available: www.adb.org/documents/information/ knowledge-solutions/enriching-policy-with-research.pdf

Department for International Development. 2009. Political Economy Analysis: How-To Note. Available: www. odi.org.uk/events/documents/1929-dfid-note-political-economy-analysis.pdf

\section{For further information}

Contact Olivier Serrat, Head of the Knowledge Management Center, Regional and Sustainable Development Department, Asian Development Bank (oserrat@adb.org).

Asian Development Bank

$A D B$ 's vision is an Asia and Pacific region free of poverty. Its mission is to help its developing member countries reduce poverty and improve the quality of life of their people. Despite the region's many successes, it remains home to two thirds of the world's poor: 1.8 billion people who live on less than $\$ 2$ a day, with 903 million struggling on less than $\$ 1.25$ a day. ADB is committed to reducing poverty through inclusive economic growth, environmentally sustainable growth, and regional integration.

Based in Manila, ADB is owned by 67 members, including 48 from the region. Its main instruments for helping its developing member countries are policy dialogue, loans, equity investments, guarantees, grants, and technical assistance.

Knowledge Solutions are handy, quick reference guides to tools, methods, and approaches that propel development forward and enhance its effects. They are offered as resources to ADB staff. They may also appeal to the development community and people having interest in knowledge and learning.

The views expressed in this publication are those of the author(s) and do not necessarily reflect the views and policies of the Asian Development Bank (ADB) or its Board of Governors or the governments they represent. $A D B$ encourages printing or copying information exclusively for personal and noncommercial use with proper acknowledgment of ADB. Users are restricted from reselling, redistributing, or creating derivative works for commercial purposes without the express, written consent of ADB.

Asian Development Bank

6 ADB Avenue, Mandaluyong City

1550 Metro Manila, Philippines

Tel +6326324444

Fax +6326362444

knowledge@adb.org

www.adb.org/knowledgesolutions 